\title{
Giant Cell Fibroblastoma
}

National Cancer Institute

\section{Source}

National Cancer Institute. Giant Cell Fibroblastoma. NCI Thesaurus. Code C4700.

A rare, locally aggressive fibroblastic neoplasm typically affecting young patients

(predominantly boys). It manifests with painless nodules in the dermis or subcutaneous tissues. Morphologically, it contains giant cells and wide vessel-like spaces. This tumor can recur but metastases have not been reported. 